\title{
SISTEM PENDUKUNG KEPUTUSAN UNTUK PENENTUAN PENERIMA BERAS RASKIN DENGAN METODE FUZZY MAMDANI
}

\author{
${ }^{1}$ Ali Ikhwan, ${ }^{2}$ Samsul Bahri Siagian, ${ }^{3}$ Siti Mawaddah, ${ }^{4}$ Melenia Annisah \\ ${ }^{1234}$ Sistem Informasi,Fakultas sains dan Teknologi \\ 1Email: ali_ikhwan@,uinsu.ac.id \\ ${ }^{2}$ Email: samsulbahrisiagian@gmail.com \\ ${ }^{3}$ Email: meleanis19@gmail.com \\ ${ }^{4}$ Email: smawaddah185@gmail.com
}

\begin{abstract}
The Raskin program is one of the poverty alleviation and social protection programs organized by the Central Government in the form of subsidized rice assistance to low-income households (poor and vulnerable households), as an effort from the government to improve food security and provide social protection at home target ladder. This program aims to reduce the expenditure burden of Households (RTS) through fulfilling some basic food needs in the form of rice and preventing a decrease in energy and protein consumption, therefore I chose fuzzy mamdani to help certain parties to distribute Raskin rice on target
\end{abstract}

Keywords: Decision support system for determining risk of risk people with fuzzy mamdani method

\begin{abstract}
Abstrak
Program Raskin adalah salah satu program penanggulangan kemiskinan dan perlindungan sosial di bidang pangan yang diselenggarakan oleh Pemerintah Pusat berupa bantuan beras bersubsidi kepada rumah tangga berpendapatan rendah (rumah tangga miskin dan rentan), sebagai upaya dari pemerintah untuk meningkatkan ketahanan pangan dan memberikan perlindungan sosial pada rumah tangga sasaran. Program ini bertujuan untuk mengurangi beban pengeluaran Rumah Tangga Sasaran (RTS) melalui pemenuhan sebagian kebutuhan pangan pokok dalam bentuk beras dan mencegah penurunan konsumsi energi dan protein, maka dari itu saya memilih fuzzy mamdani untuk membatu pihak tertentu untuk pembagian beras raskin tepat sasaran
\end{abstract}

Kata Kunci : Sistem pendukung keputusan untuk penentuan penerima beras raskin dengan metode fuzzy mamdani. 


\section{PENDAHULUAN}

Program Raskin merupakan komitmen Pemerintah dalam pemenuhan kebutuhan pangan bagi masyarakat kurang mampu (miskin). Program ini bertujuan untuk mengurangi beban pengeluaran Rumah Tangga Miskin dalam memenuhi kebutuhan pangan. Disamping itu, program juga memiliki peran untuk meningkatkan akses masyarakat miskin dalam pemenuhan kebutuhan pangan pokok sebagai salah satu hak dasar masyaraka (Indroyono, 2011).

Maka dari itu Program Raskin sangat di butuhkan Masyarakat miskin di kehidupan untuk menunjang kebutuhan terutama di daerah-daerah yang kecil, untuk penentuan siapa saya yang layak dalam penerimaan Beras Raskin di daerah maka dari itu Metode Fuzzy Mamdani sangat berguna dalam penentuan siapa saja yang berhak menerima Beras Raskin secara layak.

Untuk Pengambilan Sistem Keputusan dalam Penentuan Penerimaan Beras Raskin kita harus menentukan data dan Nilai yang akan di gunakan secara sistematis.Proses analisis dan Pengambilan Keputusan juga memiliki strategi Pendataan, data yang ada akan di integrasikan dari berbagai sumber yang menyakinkan dan yang benar, Sehingga Probabilitas data yang akan di dapatkan atau di uji Sesuai dengan Proses yang di tentukan. Maka dari itu nilai yang akurat dan data yang ada akan memastikan kualitas informasi dan Keputusan yang baik. (Sri Haryati, Ali Ikhwan, \& Diki Arisandi, 2017)

\section{TINJAUAN PUSTAKA}

\section{A. Sistem Pendukung Keputusan}

$\begin{array}{lr}\text { Sistem Pendukung } & \text { Keputusan } \\ \text { merupakan Sistem berbasis } & \text { komputer } \\ \text { yang interaktif, yang membantu } & \text { pengambil } \\ \text { keputusan dengan memanfaatkan } & \text { data dan } \\ \text { model untuk menyelesaikan } & \text { masalah } \\ \text { masalah yang tak terstruktur (Irfan, 2002) }\end{array}$

Ada yang mendefinisikan bahwa sistem pendukung keputusan merupakan suatu pendekatan untuk mendukung pengambilan keputusan. Sistem pendukung keputusan menggunakan data,memberikan antarmuka pengguna yang mudah, dan dapat menggabungkan SPK (Turban, 2005)

\section{B. Logika Fuzzy}

Logika fuzzy merupakan suatu cara untuk memetakan suatu ruang masukan ke dalam suatu ruang keluaran. Dalam teori logika fuzzy dikenal himpunan fuzzy (fuzzy set). Merupakan pengelompokan sesuatu berdasarkan variabel bahasa yang dinyatakan dalam fungsi keanggotaan (membership function).

Logika Fuzzy banyak digunakan di berbagai bidang. seperti pada sistem diagnosa penyakit (dalam bidang kedokteran), pemodelan sistem pemasaran, riset operasi (dalam bidang ckonomi), kendali kualitas air, prediks adanya gempa bumi, klasifikasi dan pencocokan pola (dalam bidang teknik). (Heru Didyo \& Effendi, 2011)

Adapun variabel-variabel nilai yang akan dimodelkan dalama Penentuan Penerima Raskin adalah suatu berikut: 
Volume 9 No.2 | Agustus 2019: 457-463

\begin{tabular}{|c|c|c|c|c|}
\hline Fungsi & Variabel & Nama Himpunan Fuzzy & Semesta Pembicaraan & Domain \\
\hline \multirow[t]{9}{*}{ Input } & \multirow[t]{3}{*}{ Bangunan Rumah } & Tidak Baik & $10-90$ & $10-40$ \\
\hline & & Baik & & $30-70$ \\
\hline & & Sangat Baik & & $60-90$ \\
\hline & \multirow[t]{3}{*}{ Pendapatan } & Rendah & $100000-500000$ & $1.000 .00-3.000 .00$ \\
\hline & & Sedang & & $2.000 .00-4.000 .00$ \\
\hline & & Tinggi & & $3.000 .00-5.000 .00$ \\
\hline & \multirow[t]{3}{*}{ Jumlah Keluarga } & Sedikit & $2-6$ & $2-4$ \\
\hline & & Cukup & & $3-5$ \\
\hline & & Banyak & & $4-6$ \\
\hline \multirow[t]{2}{*}{ Output } & \multirow[t]{2}{*}{ Evaluasi Penilaian } & Layak & $0-100$ & $50<x \leq 100$ \\
\hline & & Tidak Layak & & $0 \leq \mathrm{x} \leq 50$ \\
\hline
\end{tabular}

\section{Variabel Nilai Bagunan Rumah}

Dalam menentukan Nilai Bangunan Rumah Kita akan Membagi atas 3 himpunan Variabel fuzzy yaitu: Antara Variabel Nilai Bangunan Rumah yang Tidak Baik, Nilai Bangunan Rumah Baik, dan Nilai Bangunan Rumah Sangat Baik. Adapun penilaian Bangunan Rumah ini dapat kita lihat dari gambar fungsi keanggotaan variabel Nilai Bangunan Rumah Yang di bawah ini:

Table 1 Nilai Variabel Bangunan Rumah

\begin{tabular}{|c|c|c|c|c|c|}
\hline No & $\begin{array}{c}\text { Nama } \\
\text { Kepala } \\
\text { Keluar } \\
\text { ga }\end{array}$ & $\begin{array}{c}\text { Nilai } \\
\text { Bangun } \\
\text { an } \\
\text { Rumah }\end{array}$ & \multicolumn{3}{|c|}{ Drajat Bagunan Rumah } \\
\cline { 4 - 6 } & $\begin{array}{c}\text { Sanjiw } \\
\text { an } \\
\text { Pasarib } \\
\text { u }\end{array}$ & 20 & $\mathbf{1}$ & 0 & 0 \\
\hline 2 & $\begin{array}{c}\text { Jumant } \\
\text { Baik } \\
\text { Siagian }\end{array}$ & 40 & 0 & $\mathbf{1}$ & 0 \\
\hline 3 & $\begin{array}{c}\text { Rizky } \\
\text { Amand } \\
\text { a }\end{array}$ & 10 & $\mathbf{1}$ & 0 & 0 \\
\hline 4 & $\begin{array}{c}\text { Jaki } \\
\text { Gultom }\end{array}$ & 50 & $\mathbf{1}$ & 0 & 0 \\
\hline 5 & $\begin{array}{c}\text { Baban } \\
\text { Hutaba } \\
\text { rat }\end{array}$ & 80 & 0 & 0 & $\mathbf{1}$ \\
\hline
\end{tabular}

Gambar 1KurvaBangunanRumah

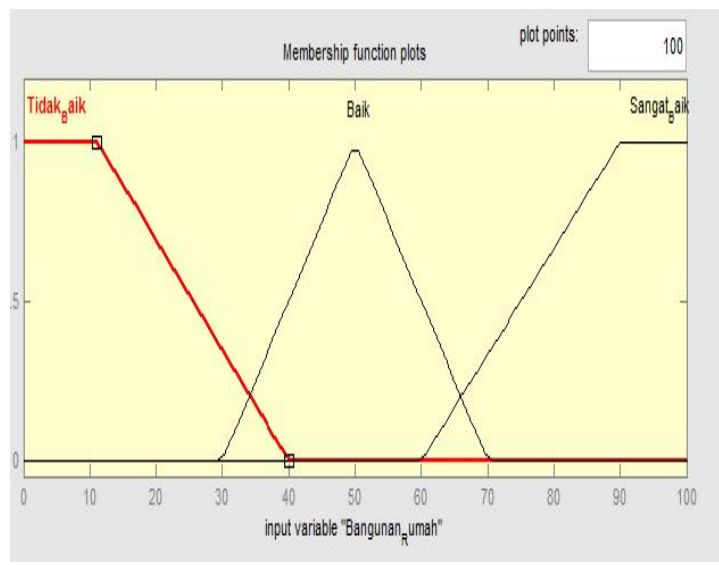

$\mu$ Tidak Baik $[\mathrm{x}]=\left\{\begin{aligned} 1 ; & x & \leq 40 \\ (10-x) /(10-40) ; & 10 & \leq x 40 \\ 0 ; & x & \geq 40\end{aligned}\right.$

$\mu$ Tidak Baik $[\mathrm{x}]=\left\{\begin{array}{crl}1 ; & x & \leq 40 \\ (10-x) /(10-40) ; & 10 & \leq x 40 \\ 0 ; & x & \geq 40\end{array}\right.$

$\mu \operatorname{Baik}[\mathrm{x}]=\left\{\begin{array}{cc}0 ; & x \leq 30 \text { atau } x \geq 70 \\ (x-30) /(50-30) ; & 30 \leq x \leq 50 \\ (70-x) /(70-50) ; & 50 \leq x \leq 70\end{array}\right.$

$\mu$ SangatBaik $[\mathrm{x}]=\left\{\begin{array}{cc}0 ; & x \leq 60 \\ (x-60) /(90-60) ; & 60 \leq x \leq 90 \\ 1 ; & x \geq 90\end{array}\right.$

\section{Variabel Pendapatan}

Dalam menentukan pendapatan dibagi ada 3 himpunan fuzzy yaitu: Pendapatan Rendah, Sedang, Tinggi. Adapun penilaian 
penapatan ini dapat dinilai dari gambar fungsi keanggotaan berikut:

Gambar 2 Kurva Pendapatan Kepala Keluarga

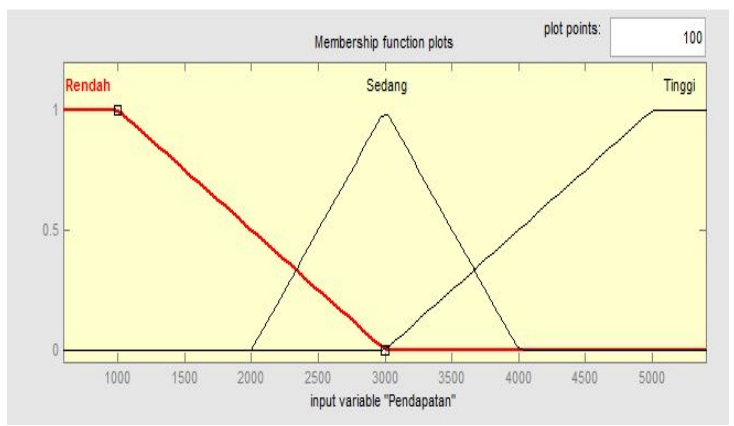

Table 2 NilaiVariabelPendapatanKepalaKeluarga

\begin{tabular}{|c|c|c|c|c|c|}
\hline No & $\begin{array}{c}\text { Nama } \\
\text { Kepala } \\
\text { Keluarga }\end{array}$ & \multirow{2}{*}{$\begin{array}{c}\text { Nilai } \\
\text { Pendapatan }\end{array}$} & \multicolumn{3}{|c|}{ Drajat Pendapatan } \\
\cline { 4 - 6 } & $\begin{array}{c}\text { Sanjiwan } \\
\text { Pasaribu }\end{array}$ & 1.500 .000 & 1 & 0 & 0 \\
\hline 2 & $\begin{array}{c}\text { Jumanto } \\
\text { Siagian }\end{array}$ & 4.200 .000 & 0 & 0 & 1 \\
\hline 3 & $\begin{array}{c}\text { Rizky } \\
\text { Amanda }\end{array}$ & 1.000 .000 & 1 & 0 & 0 \\
\hline 4 & $\begin{array}{c}\text { Jaki } \\
\text { Gultom }\end{array}$ & 5.000 .000 & 0 & 0 & 1 \\
\hline 5 & $\begin{array}{c}\text { Baban } \\
\text { Hutabarat }\end{array}$ & 3.000 .000 & 0 & 1 & 0 \\
\hline
\end{tabular}

1 ;

$\mu \operatorname{Rendah}[\mathrm{x}]=\left\{\begin{array}{c}(300.000-x) /(300.000-100.000) \\ 0 ;\end{array}\right.$

$x \leq 100.000$

$100.000 \leq x \leq 300.000$

$x \geq 300.000$

$\mu$ Sedang $[\mathrm{x}]=\left\{\begin{array}{c}0 ; \\ (\underline{x-200.000}) \\ (400.000-200.000) \\ (\underline{400.000-x)} \\ (400.000-300.000)\end{array} ;\right.$

$x \leq 200.000$ atau $x \geq 400.000$

$200.000 \leq x \leq 300.000$

$300.000 \leq x \leq 400.000$

$\mu$ Tinggi $[\mathrm{x}]=\{(x-300.000) /(500.000-300.000)$;

$x \leq 300.000$

$300.000 \leq x \leq 500.000$

$x \geq 500.000$

\section{Variabel Jumlah Keluarga}

Dalam menentukan jumlah tangungan keluarga dibagi 3 himpunan fuzzy yaitu: Jumlah Keluarga Sedikit, Jumlah Keluarga Cukup, Jumlah Keluarga Banyak. Adapun penilaian jumlah keluarga ini dapat dilihat dari gambar fungsi keanggotaan berikut:

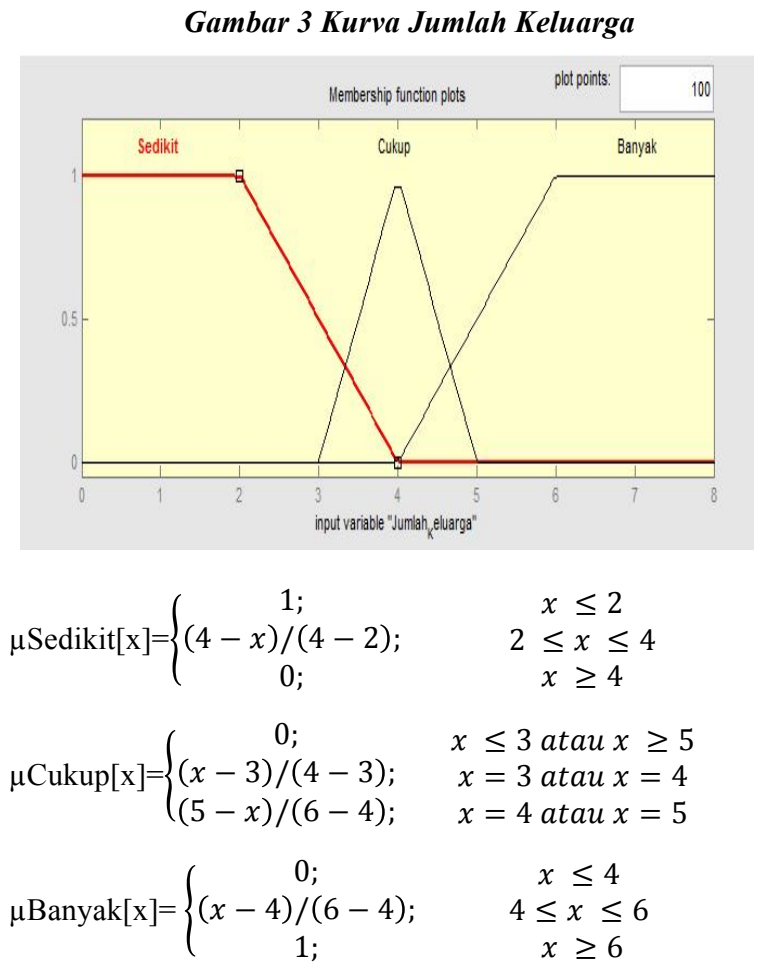

Selanjutnya Kita Cocok kan Nilai Variabel dengan Nilai yang akan di Masukkan.

Table 3 Nilai Variabel Jumlah Keluarga

\begin{tabular}{|c|c|c|c|c|c|}
\hline \multirow[t]{2}{*}{ No } & \multirow{2}{*}{$\begin{array}{c}\text { Nama } \\
\text { Kepala } \\
\text { Keluarga }\end{array}$} & \multirow{2}{*}{$\begin{array}{c}\text { Nilai } \\
\text { Kelua } \\
\text { rga }\end{array}$} & \multicolumn{3}{|c|}{ Drajat Jumlah Keluarg } \\
\hline & & & $\begin{array}{c}\text { Rend } \\
\text { ah }\end{array}$ & $\begin{array}{c}\text { Cuku } \\
\text { p }\end{array}$ & $\begin{array}{c}\text { Bany } \\
\text { ak }\end{array}$ \\
\hline 1 & $\begin{array}{l}\text { Sanjiwan } \\
\text { Pasaribu }\end{array}$ & 5 & $\mathbf{0}$ & 0 & 0,5 \\
\hline 2 & $\begin{array}{l}\text { Jumanto } \\
\text { Siagian }\end{array}$ & 4 & 0 & 1 & 0 \\
\hline 3 & $\begin{array}{c}\text { Rizky } \\
\text { Amanda }\end{array}$ & 3 & 0,5 & 0 & 0 \\
\hline 4 & $\begin{array}{c}\text { Jaki } \\
\text { Gultom }\end{array}$ & 2 & 1 & 0 & 0 \\
\hline 5 & $\begin{array}{c}\text { Baban } \\
\text { Hutabarat }\end{array}$ & 4 & 0 & 1 & 0 \\
\hline
\end{tabular}




\section{Variabel Evaluasi Penilaian}

Untuk menentukan kriteria penentuan penerimaan Bantuan siswa miskin (BSM) berdasarkan nilai kedisiplnan, pendapatan orang tua, dan tanggungan keluraga maka sebagai keluaran dikeompokkan mejadi 2 himpunan fuzzy, yaitu: layak dan tidak layak. Adapun proses penilaian ini dapat dilihat dri gambar fungsi keanggotaan dibawah ini:

Gambar 4 KurvaKeanggotaanEvaluasiPenilaian

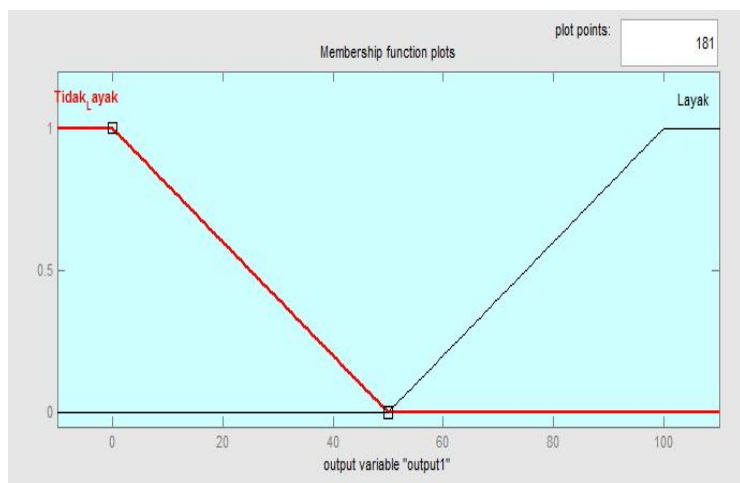

$\mu$ TidakLayak $[\mathrm{x}]=\left\{\begin{array}{cc}1 ; & x \leq 0 \\ (50-z) /(50-0) ; & 0 \leq z \leq 50 \\ 0 ; & z \geq 50\end{array}\right.$

$\mu$ Layak $[\mathrm{x}]=\left\{\begin{array}{cc}0 ; & x \leq 50 \\ (z-50) /(100-50) ; & 50 \leq z \leq 100 \\ 1 ; & x \geq 100\end{array}\right.$

\section{TAHAP PEMBENTUKAN BASIS PENGETAHUAN FUZZY}

Berisi tentang aturan yang berlaku untuk semua kejadian (kombinasi). Proses ini untuk mencari suatu nilai fuzzy output dari fuzzy input. Prosesnya adalah sebagai berikut: suatu nilai fuzzy input yang berasal dari proses fuzzifikasi kemudian dimaskkan kedalam rule yang telah dibuat untuk dijadikan sebuah fuzzy output. Adapun aturan aturan yang dipergunakan dalam penentuan penerima beras raskin dengan metode fuzzy mamdani adalah sebagai berikut:
Table 4 Hasil Nilai Variabel yang di dapat

\begin{tabular}{|c|c|c|c|c|c|c|c|c|c|c|}
\hline \multirow[t]{2}{*}{$\begin{array}{l}\text { Nama } \\
\text { Kepala } \\
\text { Keluarga }\end{array}$} & \multicolumn{3}{|c|}{$\begin{array}{l}\text { Bangunan } \\
\text { Rumah }\end{array}$} & \multicolumn{3}{|c|}{$\begin{array}{l}\text { Pendapa } \\
\text { tan }\end{array}$} & \multicolumn{3}{|c|}{$\begin{array}{l}\text { Jumlah } \\
\text { Keluara } \\
\text { ga }\end{array}$} & \multirow[t]{2}{*}{$\mathbf{R}$} \\
\hline & $\begin{array}{l}\mathbf{T} \\
\mathbf{B}\end{array}$ & B & $\begin{array}{l}\mathbf{S} \\
\mathbf{B}\end{array}$ & $\mathbf{R}$ & $\mathbf{S}$ & $\mathbf{T}$ & $\mathbf{S}$ & C & B & \\
\hline $\begin{array}{l}\text { Sanjiwan } \\
\text { Pasaribu }\end{array}$ & 1 & 0 & 0 & 1 & 0 & 0 & 0 & 0 & $\mathbf{0}$ & $\begin{array}{l}\mathbf{R} \\
22\end{array}$ \\
\hline $\begin{array}{l}\text { Jumanto } \\
\text { Siagian }\end{array}$ & 0 & 1 & 0 & 0 & 0 & 1 & 0 & 1 & 0 & $\begin{array}{l}\mathbf{R} \\
\mathbf{2 3}\end{array}$ \\
\hline $\begin{array}{l}\text { Rizky } \\
\text { Amanda }\end{array}$ & 1 & 0 & 0 & 1 & 0 & 0 & $\begin{array}{l}0 \\
5\end{array}$ & 0 & 0 & $\begin{array}{l}\mathrm{R} \\
\mathbf{1}\end{array}$ \\
\hline $\begin{array}{l}\text { Jaki } \\
\text { Gultom }\end{array}$ & 1 & 0 & 0 & 0 & 0 & 1 & 1 & 0 & 0 & $\begin{array}{l}\mathrm{R} \\
12\end{array}$ \\
\hline $\begin{array}{l}\text { Baban } \\
\text { Hutabara } \\
t\end{array}$ & 0 & 0 & 1 & 0 & 1 & 0 & 0 & 1 & 0 & $\begin{array}{l}\mathbf{R} \\
\mathbf{5}\end{array}$ \\
\hline
\end{tabular}

\section{Mesin Inferensi dan Defuzzyfikasi}

Mesin inferensi merupakan proses untuk mengolah input fuzzy menjadi output fuzzy dengan mengikuti rule yang telah ditetapkan pada basis pengetahuan fuzzy. Mesin inferensi merupakan fungsi implikasi MIN untuk mendapatkan nila a-predikat tiap rule.

Kemudian masing masing nilai digunakan untuk menghitung output, hasil inferensi secara tegas (crisp) masing masing rule (z). Sedangkan fungsi fuzzifikasi adalah untuk mengolah output yang diperoleh dari mesin inferensi menjadi nilai tegas dengan menggunakan fungsi keanggotaan yang sesuai dengan fuzzyfikasi yang ada.

Berikut adalah penjelasan $\alpha$-predikat, scrisp (z) dan hasil defuzzyfikasi (Z) Sistem Penilaian penentuan penerima Beras Raskin:

$\alpha 22=\operatorname{MIN}(\mu$ NilaiBangunanTidakBaik AND

$$
\mu \text { PendapatanRendah AND }
$$

$\mu$ JumlahKeluargaBanyak)

$=\operatorname{MIN}(1$ AND 1 AND 0,5)

$=0,7$

Berdasarkan hasil evaluasi penilaian bahwa R7 yang mempunyai derajat keanggotaan LAYAK, maka dapat dihitung nilai z7 adalah sebagai berikut: 


$$
\begin{aligned}
(\mathrm{z} 7-50) /(100-50) & =0,7 \\
(\mathrm{Z} 7-50) & =0,7 * 50 \\
\mathrm{z} 7 & =(0,7 * 50)+50 \\
\mathrm{z} 7 & =85=\text { LAYAK }
\end{aligned}
$$

\section{E. Hasil Pengujian}

Untuk Melakukan Hasil Pengujian

\begin{tabular}{|c|c|c|c|c|}
\hline \multirow[t]{2}{*}{ No } & \multicolumn{3}{|c|}{ Variabel Input } & \multirow{2}{*}{$\begin{array}{c}\text { Variabel } \\
\text { Output } \\
\text { Evaluasi } \\
\text { Penilaian }\end{array}$} \\
\hline & $\begin{array}{l}\text { Nilai } \\
\text { Bangunan } \\
\text { Rumah }\end{array}$ & $\begin{array}{l}\text { Pendapa } \\
\tan \end{array}$ & $\begin{array}{l}\text { Jumlah } \\
\text { Keluarga }\end{array}$ & \\
\hline 1 & Tidak Baik & Rendah & Sedikit & Layak \\
\hline 2 & Baik & Rendah & Sedikit & Layak \\
\hline 3 & $\begin{array}{l}\text { Sangat } \\
\text { Baik }\end{array}$ & Rendah & Sedikit & $\begin{array}{l}\text { Tidak } \\
\text { Layak }\end{array}$ \\
\hline 4 & $\begin{array}{l}\text { Sangat } \\
\text { Baik }\end{array}$ & Sedang & Sedikit & $\begin{array}{l}\text { Tidak } \\
\text { Layak }\end{array}$ \\
\hline 5 & $\begin{array}{l}\text { Sangat } \\
\text { Baik }\end{array}$ & Sedang & Cukup & $\begin{array}{l}\text { Tidak } \\
\text { Layak }\end{array}$ \\
\hline 6 & $\begin{array}{l}\text { Sangat } \\
\text { Baik }\end{array}$ & Tinggi & Cukup & $\begin{array}{l}\text { Tidak } \\
\text { Layak }\end{array}$ \\
\hline 7 & $\begin{array}{l}\text { Sangat } \\
\text { Baik }\end{array}$ & Tinggi & Banyak & $\begin{array}{l}\text { Tidak } \\
\text { Layak }\end{array}$ \\
\hline 8 & Baik & Tinggi & Banyak & $\begin{array}{l}\text { Tidak } \\
\text { Layak }\end{array}$ \\
\hline 9 & $\begin{array}{l}\text { Sangat } \\
\text { Baik }\end{array}$ & Sedang & Sedikit & Layak \\
\hline 10 & $\begin{array}{l}\text { Sangat } \\
\text { Baik }\end{array}$ & Rendah & Sedikit & Layak \\
\hline 11 & Tidak Baik & Sedang & Cukup & Layak \\
\hline 12 & Tidak Baik & Tinggi & Sedikit & Layal \\
\hline 13 & Tidak Baik & Sedang & Banyak & Layak \\
\hline 14 & Baik & Rendah & Banyak & $\begin{array}{l}\text { Tidak } \\
\text { Layak }\end{array}$ \\
\hline 15 & $\begin{array}{l}\text { Sangat } \\
\text { Baik }\end{array}$ & Rendah & Cukup & $\begin{array}{l}\text { Tidak } \\
\text { Layak }\end{array}$ \\
\hline 16 & $\begin{array}{l}\text { Sangat } \\
\text { Baik }\end{array}$ & Sedang & Banyak & $\begin{array}{l}\text { Tidak } \\
\text { Layak }\end{array}$ \\
\hline 17 & $\begin{array}{l}\text { Sangat } \\
\text { Baik }\end{array}$ & Tinggi & Cukup & $\begin{array}{l}\text { Tidak } \\
\text { Layak }\end{array}$ \\
\hline 18 & $\begin{array}{l}\text { Sangat } \\
\text { Baik }\end{array}$ & Tinggi & Sedikit & $\begin{array}{l}\text { Tidak } \\
\text { Layak }\end{array}$ \\
\hline 19 & Baik & Rendah & Cukup & Layak \\
\hline 20 & Baik & Sedang & Cukup & Layak \\
\hline 21 & Baik & Sedang & Sedikit & Layak \\
\hline 22 & Tidak Baik & Rendah & Banyak & Layak \\
\hline 23 & Baik & Tinggi & Cukup & $\begin{array}{l}\text { Tidak } \\
\text { Layak }\end{array}$ \\
\hline
\end{tabular}
Terhadap Matlab dapat kita lakukan sebagai berikut:

Table 5 Rule Penentu Penerimaan Raskin 
Volume 9 No.2 | Agustus 2019: 457-463

I. S. (2002). Sistem Pendukung Keputusan (

Decision Support System ). Yogyakarta:

Graha Ilmu.

T. E. (2005). Decision Support Systems and Intelligent Systems Edisi Bahasa Indonesia Jilid 1. Yogyakarta: Andi.

I. S. (2011). Pedoman Umum Raskin Beras Bersubsidi untuk Rumah Tangga Miskin. Jakarta : Kementrian Koordinator Bidang Kesejahteraan Rakyat Republik Indonesia. 